\title{
Robert Latimer: Bait and switch
}

$\mathrm{L}$ ike a street game of 3-card monty in which the money card is switched during a fast shuffle, the December 2007 furor over Robert Latimer's failed request for day-parole was not really about Latimer, or the parole board's decision. It was very much about whether in Canada we will kill the fragile among us, and, if we do, who will decide which life is unworthy of living.

Neither in his various court appearances nor at his National Parole Board hearing has Latimer ever denied killing his I2-year-old daughter, Tracy, who was born with cerebral palsy. His supporters do not dispute this either, and, like Latimer himself, see nothing particularly heinous in her murder. Those seeking Latimer's speedy parole include, in a partial list, the Canadian Civil Liberties Union, the Green Party of Canada, newspaper columnists and radio hosts.

The parole board denied Latimer early parole not because he is unrepentant ("I still don't feel guilty because I still feel it was the best thing to do"'), but because he could not say he would not kill others in the future. Considering the board's legal mandate for public protection under the Corrections and Conditional Release Act, the decision was certainly reasonable. After all, Latimer has an elderly parent, a wife, other children, and a legion of supporters who might become ill and seem to Latimer candidates for termination.

Civil libertarians sought to end Latimer's "ordeal" immediately following the parole decision while columnists thundered about Latimer's "persecution." ${ }^{2}$ Others called for clemency and an end to Latimer's "suffering." All of this was a bait and switch whose subject might be Latimer but whose object is the advancement of "mercy killing" and "compassionate homicide" as, at worst, a minor crime in Canada.

To argue Latimer's early release is to insist his daughter's homicide was not a serious offence. In this argument his supporters accept without question La- timer's assertion that murder was the best and only way to love his daughter. But in this and other "compassionate homicides" - for example, Jean Brush's 1994 murder of her husband Cecil in Ontario ${ }^{3}$ - the "mercy" received was not the patient's but the release of a distraught, overwhelmed caregiver.

Only Robert Latimer saw his daughter's state as so dire as to justify her killing. Others, including his wife, saw instead a child who, despite real challenges, knew joy and pleasure. The Supreme Court of Canada decision noted that "Tracy enjoyed music, bonfires, being with her family and the circus. She liked to play music on a radio, which she could use with a special button. Tracy could apparently recognize family members and she would express joy at seeing them. Tracy also loved being rocked gently by her parents."

And there were alternatives to Tracy's murder, the court noted. Latimer rejected a feeding tube that would have aided both Tracy's nutrition and palliation; refused as well palliative surgeries he called "mutilation." ${ }^{\prime 4}$ Also declined was Tracy's placement in a group home where she would have received skilled care. In short, Latimer rejected everything but termination for his daughter.

To make of Tracy's murder an act of "compassion" and a minor crime, is to accept that anyone can kill a fragile relative out of "mercy." That is odious, and brings into question the work of all who labour for and with the fragile. It violates the strictures of good medicine and its palliative power, as well as the structure of supported care we, in Canada, have laboured to create.

Certainly, let us again debate eugenics and euthanasia. But let us do so honestly and not through indirection. Latimer's supporters do us all a disservice by suggesting Latimer's crime was minor, and his continued incarceration unreasonable. Robert Latimer is no exemplar, his supporters neither humanists nor libertarians. The proof: In all

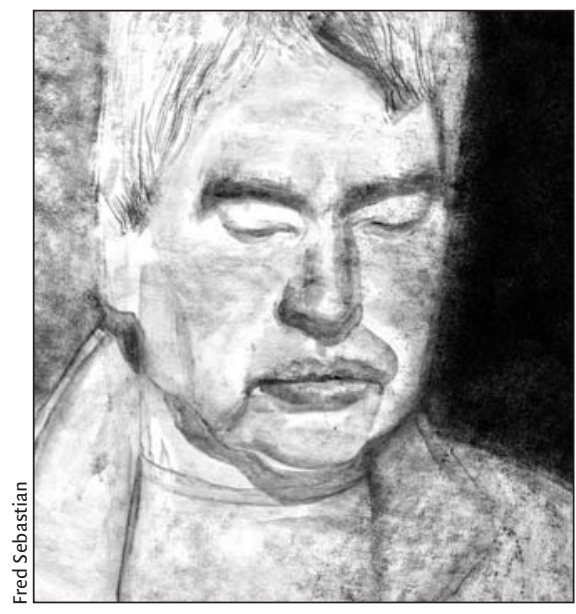

the platitudes written about Latimer's parole nobody talked of the I2-year-old girl who loved music, bonfires and being hugged by her parents, one of whom killed her. For Latimer's public supporters, Tracy Latimer was as disposable as yesterday's newspaper.

\section{Tom Koch $\mathrm{PhD}$ \\ Bioethicist \\ Vancouver, BC}

Tom Koch PhD is a bioethicist for the Canadian Down Syndrome Society (Resource Council).

\section{REFERENCES}

I. Shaw, R. Latimer denied parole for killing disabled daughter. Victoria Times-Colonist 2007 Dec 5;Sect A:I.

2. Mulgrew, I. Robert Latimer has been persecuted, not prosecuted. Vancouver Sun 2007 Dec Io; Sect B:I.

3. Koch, T. The myth of loving murder. Toronto Life Magazine December 1995: 6I-8.

4. R. v. Latimer, I S.C.R. 3, 200I SCC I.

5. A terrible decision on Robert Latimer [editorial]. Globe and Mail 2008 Dec 6;Sect A:I8.

Salon's mission is to present a diversity of views in a manner that permits a civil, but vibrant, exchange of perspectives. In the next issue, Dr. Ken Walker will present his views on the Latimer controversy. Potential Salon contributors are welcome to send a query to salon@cma.ca. 